bars, south of Weldon, the sea-bottom is totally distinct in character, being purely submarine, and formed by the action of the sea. He points out the existence of a rise and fall of the coast at different portions of its extent; this, in the most recent geological period, amounting at Charleston, South Carolina, to from 50 to $60 \mathrm{feet}$, in Maine to 200 feet, and to a still greater extent on the coast of Labrador. As a general rule, he thought there was evidence to prove that, taking a line from the centre of the continent to the centre of the sea, the sea-floor was coming up and the high elevations were coming down.Mr. Hyat states that observations made by the Coast Survey showed that the coast of Long Island Sound, and southward to New Jersey, has been sinking, while the Florida Keys are rising; and Mr. Niles remarked that, from the earliest times, in the Adirondacks and different points sou herly, there had been peninsulas corresponding in position to Florida, and that this is simply the most southern and latest of a succession from north to south.At a meeting of the New York Lyceum of Natural History, held during last autumn, Prof. Newberry, the President, exhibited the anterior portion of the cranium of a walrus which had been found during the summer at Long Branch by a gentleman whose foot struck against it while bathing. It was strongly silicified, but exhibited no appreciable difference from modern specimens. The precise age of this fossil could not, of course, be ascertained, although it is well known that its range was formerly much south of its present habitat. It is not unfrequently brought down on floating ice off the coast of Newfoundland; and although Labrador is at present the southern Jimit of its residence, it was once very abundant in the Gulf of St. Lawrence, and its remains have been found in the shell heaps of the Bay of Fundy. It is probable that the specimen exhibited by Prof. Newberry is a relic of the glacial period, although it was suggested that it might have been of the tertiary age, which probably cannot be verified. Other specimens of similar character are recorded as having been found on Martha's Vin eyard; in Monmouth Co., New Jersey; and in Accomac Co., Virginia - We have already referred to the detection of an ancient bone cave near Phœnixville, Pennsylvania, and about twenty-five miles north-west of Philadelphia, and to the interest which has attached to this discovery. Since our last account Prof. Cope has been actively engaged in the investigation of the collection, and already reports the existence of about thirty species of vertebrates, together with numerous plants and insects. All of these, so far as known, are probably of extinct species, although their precise relationships have not yet been fully worked out. Among the reptiles were tortoises and serpents, and of birds there was a turkey and a snipe. The mammals, as Prof. Cope anticipated, were most numerous, these including two carnivorous animals of large size, one of them a cat, and the other a bear, previously described by Dr. Leidy, of a remarkable type, and totally distinct from the cave bear, or any living species of either Europe or America. At least three species of sloths were discovered, mostly of gigantic size, one of them a species of Megalonyx, and two of Mylodon. Besides these, there were some ruminating animals, tapirs, and a small horse. With the other remains were the teeth and tusks of the mastodon. The fissure in which the bones were found was forty feet deep and fifteen feet wide ; the length as yet has not been determined. Above the deposit of bones the cave was filled with washings of the Triassic age from the neighbouring hills.

\section{SCIENCE AT OXFORD}

THE following courses of lectures in Science are announced for the ensuing term :- The Regius Professor of Medicine (Dr. Acland) will continue his clinical instruction at the Infirmary, on Tuesdays and Saturdays, beginning on Tuesday, May 2, at II A.M. The Linacre Professor of Anatomy and Physiology (Dr. Rolleston) proposes to form classes for practical instruction in anatomy and physiology, as in former terms. Persons are invited to come to the anatomical department in the New Museum on two mornings of the week for study and demonstration, and to lectures on Saturdays at I P.M., and at such other times as may be hereafter arranged. The Sedleian Professor of Natural Philosophy (the Rev. Bartholomew Price) will give a course of lectures on the Solution of Problems in Applied Mathematics. The course will begin at I P.M. on Thursday, April 20, in the lecture-room, upper corridor south, Museum. The Savilian Professor of Astronomy (the Rev. C. Pritchard) will give a lecture early in the present term on the recent solar eclipse. He will also be ready to assist members of the University in their astronomical studies, "sine ulta solennitate." The Savilian Professor of Geometry (Mr. Henry Smith) will continue his lectures on the Anharmonic Properties of Figures. $\mathrm{He}$ will also give a course of lectures on Geometry of Three Dimensions. The Professor of Geology (Mr. J. Phillips) will begin a course of lectures on Monday, April 24 , at 12 o'clock, and continue them at the same hour on succeeding Wednesdays and Mondays, in the New Museum. The lectures are arranged to present a systematic view of the more remarkable groups of organic remains, especially in the extinct groups. The Professor of Experimental Philosophy (Mr. R. B. Clifton) has given notice that the Physical Laboratory of the University will be open daily for instruction in practical physics, from IO A.M. to 4 P.M., on and after Wednesday, April r9. The fee for working three days a week during the term is $3 l$. The Professor of Chemistry (Sir B. Brodie) has given notice that the Demonstrator in Chemistry will deliver a course of lectures on Chemistry on Tuesdays and Saturdays, at II A.M., commencing Tuesday, April 25. These lectures will be in continuation of the course of the Professor of Chemistry last term, and will commence with the element phosphorus and its combinations. The Professor of Botany (Mr. Lawson) will give a course of lectures on Structural and Physiological Botany. The Hope Professor of Zoology (Mr. Westwood) proposes to give a short course of lectures on the Articulated Animals.

\section{SETTLE CAVE EXPLORATION}

$A^{T}$ the last meeting of the Settle Cave Exploration A Committee, the report of the excavation of the Victoria Cave, up to December 3Ist, 1870, by Mr. Boyd Dawkins, was read.

The results of the exploration are full of interest, and bid fair to throw light on the social condition of the Romano-Celtic inhabitants of Ribblesdale after the withdrawal of the Roman legions. The committee placed the superintendence of their exploration in the charge of $\mathrm{Mr}$. Jackson, the discoverer of the cave, and began work with the kind permission of the owner (Mr. Stackhouse), by clearing away a mass of debris, which very nearly blocked up the lower entrance and formed a horizontal plateau extending some thirty feet from the solid rock. On the surface there was a stratum of angular stones which had fallen from the weathered face of the rock above, and passed into the cave at the bottom of the Attermire ravine. Below was the layer which furnished traces of man. Mixed with charcoal there were large quantities of the bones and teeth of the Celtic short-horn (Bos longifrons), goat, and horse, and a few remains of red deer and roe deer, which were evidently the refuse of human food. There were also fragments of pottery, bone pins, and various nondescript articles in antler and bone, stone pot-boilers, and two perforated discs of stone which had been used as spindle-whorls. As this layer passed into the cave, it rose to the surface and continued to 
furnish the same class of remains as those found outside. The personal ornaments are the most worthy of note. Besides bronze harp-shaped brooches of the common late Roman type, there were two in gilt-bronze, of a sigmoid shape, and adorned with a singularly beautiful pattern in blue, yellow, red, and green enamel. They are undoubtedly of a style purely Celtic. A harp-shaped brooch, Roman in design, is adorned with a most delicate pattern in blue and red enamel. Among the other brooches, one small oblong enamel is of a form hitherto unknown in brooches of this date, while a second consists of a small disc of bronze, with a plate soldered to it bearing a flamboyant ornament of Celtic design. There were also bronze gilt armlets. The whole evidence furnished by the personal ornaments in a word points to their Romano-Celtic origin, and it is not improbable that the principal seat of the art of enamelling was Yorkshire, the few enamels of that particular kind which have been found occurring, with one or two exceptions, in that county. The date of the occupation is shown by the coins, which range from Trajan down to the barbarous imitations of the coins of Tetricus. The latter were in circulation in the fourth and fifth centuries, and probably continued to be used in that portion of the Romano-Celtic kingdom of Strathclyde down to its final conquest by Eadberht in 756 A.D. The whole group of remains is precisely of the same character as those found around the ruins of Roman villas in Britain, and has probably been introduced by Romano-Celtic in habitants who fled from their luxurious homes to take refuge from the ravages of the Picts or Scots, or of the Northumbrian Angles, who were pressing on that portion of the frontier of Strathclyde during the 5 th, 6 th, and 7 th centuries. To suppose that people using articles of luxury such as those found in the cave would have chosen such an inclement abode, except under the pressure of necessity, is unreasonable.

At the entrance below the Romano. Celtic strata a layer of angular debris fallen from the cliff above, six feet thick, rested on a thick deposit of gray clay. At their point of junction a curious bone harpoon, a bone bead, the remains of red deer, horse and Celtic short-horn, and of bear, were found, which testified to the occupation of the cave by man long before the Romano-Celts used it as a refuge. The two flint flakes and two lumps of red ruddle found were probably obtained from this lower horizon, which, as the talus died away at the entrance of the cave, became confused inside with the Romano-Celtic stratum immediately above. It is probably of Neolithic age.

The grey clay underneath was homogeneous and very tenacious, and as the layer dipped away from the entrance, it must have been introduced by water flowing from the ravine into the cave. It was resolved to give up the attempt to fathom this bed of clay, after sinking a shaft twentyfive feet deep without any results.

The committee are desirous of exploring others of the many caves in the neighbourhood, if they can obtain support necessary to carry on a work which is of almost equal interest to the archæologist and to the historian.

\section{NEW SPECIES OF MADREPORE}

M R. W. SAVILLE KENT read a paper at a recent I meeting of the Zoological Society on various new species of Madrepores, or Stony Corals, met with by himself while engaged upon arranging, naming, and cataloguing the fine series contained in the British Museum. Among the more interesting of these, commencing with the family of Turbinolidæ, Mr. Kent drew attention to a fine species of Acanthocyathus from Japan, more closely allied to a Maltese Miocene form $(A$. Hastings $a)$ than to any known existing one; and also to a Flabellum allied to $F$. Anthobhyllites, whose most remarkable feature rests in the phenomena connected with its reproduction by the process of gemmation, which invariably results in the destruc- tion of the parent; the reproductive bud always originating within the margin of the parent calyx, which, in the course of its development, it splits to pieces. For this aberrant form Mr. Kent proposes the appropriate name of Flabellum matricidum. In the family of the Oculinidæ, which comprises the majority of the species introduced by Mr. Kent, are three new forms of Allopora, and numerous ones of Stylaster, Distichopora and Amphihelia, the first-named genus in particular containing a magnificent arborescent species, upwards of a foot in height, of a delicate rose colour, having a stem of such thickness and of such dense consistence that Mr. Kent is of the opinion that, if procurable in any quantity, it may eventually prove of high economic value, and even replace to some extent the well-known Corallizun rubrum. The examination of these new varieties has enabled $\mathrm{Mr}$. Kent to define more precisely the characters of Allopora, and its true distinctions from Stylaster, Distichopora, and other allied genera. In all, Mr. Kent introduces some twenty species as new to science.

\section{SUBTERRANEAN ELECTRICAL DIS- TURBANCES}

A FEW minutes before and after the earthquakes of the 17 th March last powerful positive electrical currents were rushing towards England through the two Anglo-American telegraph cables, which are broken near Trinity Bay, Newfoundland. Mr. C. F. Varley, C.E., who informed us of the fact, broaches the novel speculation that some earthquakes may be due to subterranean lightning. He imagines that as the hot centre of the earth is approached, a layer of hot dried rock may be found which is an insulator, while the red hot mass lower down is a conductor. If this conjecture be true--and there is plausibility in it-then the world itself is an enormous Leyden jar, which only requires charging to a very moderate degree to be equal to the production of terrific explosive discharges.

The French Atlantic cable was disturbed at the same time, and so were many of the English land-lines, but the only observations as to the direction of the current were made by means of the Anglo-American telegraph cables.

A number of Mr. Varley's charts about earth-currents were published in the Government Blue Book of I85960 , showing that the direction of these currents across England was in a very notable degree determined by the contour of the coast, and that the same auroral discharges would often produce currents at right angles to each other in direction, in different parts of Britain.

\section{NOTES}

A PROPOSAl has been made that;" certain Medical Schools on the north and south sides of the river should be amalgamated, in order that, by concentration of power, the teaching shall be made more efficient than it is at present, the teachers being able to devote themselves more unreservedly to their duties than they possibly can do under existing arrangements. The absolute necessity of some such arrangement as this is obvious.

MR. RUTHERFORD and M. Janssen, to whose labours cosmical physics owes so much, are both now in this country, the former, we regret to learn, in conseguence of a peremptory order to cease work for a time. At the last meeting of the Royal Astronomical Society, Mr. Rutherford exhibited his exquisite photograph of the Pleiades, which represents the last important outcome of celestial photography. It appears that M. Janssen's observatory for solar research, which had been erected in one of the pavilions of the Palace of St. Cloud, at the cost of the Emperor, was one of the first buildings to be entirely destroyed by the German fire. 